\title{
To Study the Osmotic Dehydration Characteristics of Kiwifruit (Actinidia delicosa) Slices
}

\author{
Namneet Kaur $^{1 *}$, Naveet Kaushal ${ }^{1}$, Ajay Singh ${ }^{2}$ and Manpreet Kaur ${ }^{1}$ \\ ${ }^{1}$ Department of Agriculture, ${ }^{2}$ Department of Food Technology, Mata Gujri College, \\ Fatehgarh Sahib, India \\ *Corresponding author
}

\begin{abstract}
A B S T R A C T
Keywords

kiwifruit,

Temperature,

Concentration, Sugar,

Osmotic dehydration

Article Info

Accepted:

15 June 2018

Available Online:

10 July 2018

Kiwifruit slices were immersed in a solution containing sugar solution of 30,45 and $60^{\circ}$ Brix for about $1 \mathrm{~h}$, at three different osmotic solution temperatures 30,40 and $50^{\circ} \mathrm{C}$.The effect of process parameters (such as duration of osmosis, syrup concentration and syrup temperature) on mass transport data (such as water loss, solid gain and mass reduction) during osmotic dehydration was studied. After $1 \mathrm{~h}$ of osmotic dehydration, the minimum and maximum mass reduction, water loss and sugar gain were in the range of 32.50 to $43.74,36.30$ to 55.82 and 6.88 to 11.82 per cent corresponding to low levels $\left(30^{\circ}\right.$ Brix, $\left.30^{\circ} \mathrm{C}\right)$ and high levels $\left(60^{\circ}\right.$ Brix, $50{ }^{\circ} \mathrm{C}$ ) of syrup concentration and temperature respectively.
\end{abstract}

\section{Introduction}

Kiwifruit (Actinidia deliciosa) belongs to family Actinidiaceae with chromosome no. (2n) 58. Its primary origin is China and secondary origin is New Zealand. Area under cultivation in India is 4000 ha with production and productivity of $1100 \mathrm{mt}$ and $3 \mathrm{mt} / \mathrm{ha}$ (nhb.gov.in 2016-17). It is a temperate fruit crop. Kiwifruit is also known as Chinese gooseberry and horticultural wonder of New Zealand. In India it is cultivated in Himachal Pardesh. Kiwifruit is known for its flavour and vitamin $\mathrm{C}$ content. It is a climacteric fruit and is very sensitive to ethylene. Botanically, kiwifruit is a berry with various locules filled with many small and soft black seeds. Its flesh is separated into three regions: the outer pericarp, the inner pericarp with seeds, and the columella (core). Each part differs from the others with respect to composition and texture. The columella is lighter than the inner and outer pericarps. Kiwifruit belongs to family Actinidiaceae and genus Actinidia (Guroo et al., 2017).

Many researchers have studied osmotic dehydration of various fruits and vegetables, such as apple, banana, carrot, cherry, citrus fruits, guava, mango, etc. (Torreggiani and 
Bertolo, 2001). The osmotic dehydration process has been studied and used as a pretreatment prior to further processing such as convective-drying (Pisalkar et al., 2011). Very few attempts have been made to study osmotic dehydration characteristics of kiwifruit. Therefore, a study was proposed to investigate osmotic dehydration characteristic of kiwifruit.

Osmotic dehydration is one of the less energy intensive techniques than air or vacuum drying process because it can be conducted at low or ambient temperature. It is the process of water removal by immersing water containing cellular solids in concentrated aqueous solution. The driving force for water removal is the concentration gradient between the solution and the intracellular fluid. If the membrane is perfectly semi-permeable, solute is unable to diffuse through the membrane into the cell. However, it is difficult to obtain a perfect semi-permeable membrane in food systems due to their complex internal structure and there is always some solid diffusion process. The water and acid diffuse at faster rates initially and get reduced at later stage, while solute from concentrated solution diffuses in opposite direction. The solute penetration in food material is less at first, but increases with respect to time. The solute (sugar) penetration in the fruit directly affects the quality i.e. both flavour and taste of the end product (Kedarnath, et al., 2014).

\section{Materials and Methods}

A widely grown fruit kiwifruit ( $c v$ Bruno) was selected for the osmotic dehydration experiment. Food grade sugar was used as an osmotic agent being cheap and easily available. Ripened kiwifruit of uniform size, colour and firm texture were taken for experiment. Selected fruits were thoroughly washed under tap water to remove adhering impurities before slicing the fruit. The outer skin of the ripened fruit was carefully peeled off manually using a sharp stainless steel knife without damaging the pulp. The peeled kiwifruit fruits were cut into about 4-5 mm thick slices for the experiment. Sugar syrups of various concentrations were prepared by dissolving required amount of sugar in distilled water.

Sugar syrup of 30, 45 and 60 o Brix concentration was prepared by adding the required amount of sugar in distilled water and the total soluble solids of prepared syrup were determined by hand refractometers of various ranges (0-32, 28-62 and 58-92 ${ }^{\circ}$ Brix). The moisture content of the fresh as well as osmotically dehydrated kiwifruit samples was determined by oven drying at $50{ }^{\circ} \mathrm{C}$ for $9 \mathrm{~h}$ (Ranganna, 2000).

Experiments were conducted at nine combination of three concentrations $(30,45$ and $60^{\circ}$ Brix) and three temperatures (30, 40 and $50{ }^{\circ} \mathrm{C}$ ). The prepared samples (kiwifruit slices) were weighed approximately $40 \mathrm{~g}$ for every experiment and immersed in the sugar syrup (30, 45 and $60^{\circ}$ Brix) contained in a 250 $\mathrm{ml}$ glass beaker. The beakers were placed inside the constant temperature water bath. The syrup in the beakers was manually stirred at regular intervals to maintain uniform temperature. One beaker was removed from the water bath at designated time and placed on tissue paper to remove the surface moisture. The samples were weighed and their moisture contents were determined. The water loss and solid gain were calculated based on mass balance. All the experiments were replicated thrice and results reported are from average value of three replications.

\section{Water loss or Mass transfer out}

Water loss is the quantity of water lost by food during osmotic process. The water loss (WL) is defined as the net weight loss of the fruit on 
initial weight basis and is estimated as follows.

$$
\mathrm{WL}=\frac{\mathrm{W}_{\mathrm{i}} \cdot \mathrm{X}_{\mathrm{i}}-\mathrm{W}_{\Theta} \cdot \mathrm{X}_{\Theta}}{\mathrm{W}_{\mathrm{i}}}
$$

\section{Mass reduction}

The overall exchange in the solid and liquid of the sample do affect the final weight of the sample. The mass reduction (MR) can be defined as the net weight loss of the fruit on initial weight basis.

$$
\mathrm{MR}=\frac{\mathrm{W}_{\mathrm{i}}-\mathrm{W}_{\Theta}}{\mathrm{W}_{\mathrm{i}}}
$$

\section{Solid gain or Mass transfer in}

The solids from the osmotic solution get added in the sample of kiwifruit slices during osmotic dehydration. The loss of water from the sample takes place in osmotic dehydration consequently it increases the solid content. The solid gain is the net uptake of solids by the kiwifruit slices on initial weight basis. It is computed using following expression:

$$
\mathrm{SG}=\frac{\mathrm{W}_{\Theta}\left(1-\mathrm{X}_{\Theta}\right)-\mathrm{W}_{\mathrm{i}}\left(1-\mathrm{X}_{\mathrm{i}}\right)}{\mathrm{W}_{\mathrm{i}}} \times 100
$$

From Equations (3.2) and (3.3), the solid gain (SG) can be correlated with mass reduction (MR) and water loss (WL) as,

$\mathrm{SG}=\mathrm{WL}-\mathrm{MR}$

Where,

$\mathrm{WL}=$ water loss ( $\mathrm{g}$ per $100 \mathrm{~g}$ mass of sample), $\mathrm{SG}=$ solid gain (g per $100 \mathrm{~g}$ mass of sample) $\mathrm{MR}=$ Mass reduction $(\mathrm{g}$ per $100 \mathrm{~g}$ mass of sample),
$\mathrm{W}_{\Theta}=$ mass of slices after time $\Theta, \mathrm{g}$,

$\mathrm{W}_{\mathrm{i}}=$ initial mass of slices, $\mathrm{g}$,

$\mathrm{X}_{\Theta}=$ water content as a fraction of mass of slices at time $\Theta$ $X_{i}=$ water content as a initial mass of slices, fraction.

\section{Results and Discussion}

\section{Water loss}

The water loss increased from 0 to 36.30 , 37.64 and 39.64 per cent when duration of osmotic dehydration increased from 0 to $1 \mathrm{~h}$ for $30^{\circ}$ Brix at 30,40 and $50^{\circ} \mathrm{C}$ temperatures respectively. For $45^{\circ}$ Brix, the water loss was found to vary from 0 to $44.10,47.22$, and 47.84 per cent and similarly at $60^{\circ}$ Brix was found to vary from 0 to $51.69,54.04$ and 55.82 per cent at 30,40 and $50^{\circ} \mathrm{C}$ respectively.

Figure 1 revealed that a low temperature - low concentration condition $\left(30^{\circ} \mathrm{C}-30^{\circ}\right.$ Brix $)$ resulted in a low water loss (36.30 per cent after $1 \mathrm{~h}$ of osmosis) and a high temp - high concentration condition $\left(50^{\circ} \mathrm{C}-60^{\circ}\right.$ Brix) resulted in a higher water loss (55.82 per cent after $1 \mathrm{~h}$ of osmosis). This indicates that water loss can be increased by either increasing the syrup temperature or concentration of solution. Similar results have been reported for osmotic dehydration of bananas by (Sagar, 2001).

Figure 2 shows the variation in water loss in 30,45 and $60{ }^{\circ}$ Brix concentrations at temperatures 30,40 and $50^{\circ} \mathrm{C}$. The water loss was found increasing with increasing osmotic solution concentrations at all the three solution temperatures i.e. at 30,40 and $50^{\circ} \mathrm{C}$.

These findings were in confirmation with the results obtained. In all the experiments, the rate of water loss was more in the beginning of process and decreased gradually with the 
increase of duration of osmosis and approaches equilibrium. The similar results were quoted in case of the osmotic dehydration of banana slices (Pokharkar and Prasad, 1997).

Increased water loss with increase in syrup concentration at a particular temperature of syrup may be due to increased osmotic pressure in the syrup at higher concentrations, which increased the driving force available for water transport. This is in agreement with (Nieuwenhuijzen et al., 2001).

\section{Sugar gain}

The sugar gain was increased from 0 to 6.88 , 7.20 and 7.78 per cent when duration of osmotic dehydration increased from 0 to $1 \mathrm{~h}$ for $30^{\circ}$ Brix concentration at 30,40 and $50^{\circ} \mathrm{C}$ syrup temperatures respectively. For $45^{\circ} \mathrm{Brix}$ concentration, the sugar gain was found to vary from 0 to $8.93,9.32$ and 9.93 and for 60 ${ }^{\circ} \mathrm{Brix}$ it varied from 0 to $11.02,11.45$ and 11.82 percent for 30,40 and $50^{\circ} \mathrm{C}$ syrup temperature.

Figure 3 shows that sugar gain increased with duration of osmosis and approaches the equilibrium after 1 hour of osmotic dehydration. The sugar gain also increased when the concentration of the syrup was increased. This is because of the increased concentration difference between samples. The sugar gain also increased with increase in syrup temperature. It may be due to collapse of the cell membrane at higher temperatures. Similar results have been reported by (Nsonzi and Ramaswamy, 1998).

Figure 4 shows the variations in sugar gain at various temperatures at 30,45 and $60^{\circ}$ Brix concentrations.

A low temperature-low concentration condition $\left(30^{\circ} \mathrm{C}-30{ }^{\circ} \mathrm{Brix}\right)$ gives a low sugar gain (6.88 per cent after $1 \mathrm{~h}$ of osmosis) and a high temp-high concentration condition $\left(50^{\circ} \mathrm{C}\right.$ $-60{ }^{\circ}$ Brix) gives a higher sugar gain (11.82 per cent after $1 \mathrm{~h}$ of osmosis). The low temperature-high concentration condition $30^{\circ} \mathrm{C}-45^{\circ}$ Brix and $30^{\circ} \mathrm{C}-60^{\circ}$ Brix gives a slightly lower sugar gain of 8.93 and 11.02 after $1 \mathrm{~h}$ of osmosis than high temperaturehigh concentration condition $50^{\circ} \mathrm{C}-45^{\circ} \mathrm{Brix}$ and $50^{\circ} \mathrm{C}-60^{\circ}$ Brix as 9.93 and 11.82 per cent sugar gain after ( $1 \mathrm{~h}$ of osmosis) indicates a pronounced effect of temperature on sugar gain.

This indicates that sugar gain can be increased by either increasing the syrup temperature or concentration of solution.

However, an increase in temperature of sugar solution by $10^{\circ} \mathrm{C}$ has more influence on sugar gain than an increase in concentration by 15 ${ }^{\circ}$ Brix, may be because of higher temperature causes destruction of cell membrane structure. Similar results have been reported by (Lazarides et al., 1995) with osmotic dehydration of apple slices in a temperature range of $20-50^{\circ} \mathrm{C}$.

\section{Mass reduction}

The mass reduction after osmotic dehydration was found to be in the range of 32.50 to 43.74 per cent, corresponding to experiments at low level $\left(30^{\circ} \mathrm{Brix}, 30^{\circ} \mathrm{C}\right.$ after $\left.1 \mathrm{~h}\right)$ and at high level $\left(60^{\circ}\right.$ Brix, $50^{\circ} \mathrm{C}$ after $\left.1 \mathrm{~h}\right)$ (Fig. 5).

The mass reduction increased from 0 to 32.50 , 36.30 and 40.52 percent when duration of osmotic dehydration increased from 0 to $1 \mathrm{~h}$ at 30,40 and $50^{\circ} \mathrm{C}$ temperatures respectively for $30^{\circ}$ Brix while for $45^{\circ}$ Brix, the mass reduction was found to vary from 0 to $33.13,38.27$ and 42.63 per cent and for $60^{\circ}$ Brix from 0 to $34.74,40.46$ and 43.74 per cent at 30,40 and $50^{\circ} \mathrm{C}$ respectively. 
Fig.1 Variation in water loss with sugar syrup concentration at 30,40 and $50^{\circ} \mathrm{C}$ temperature

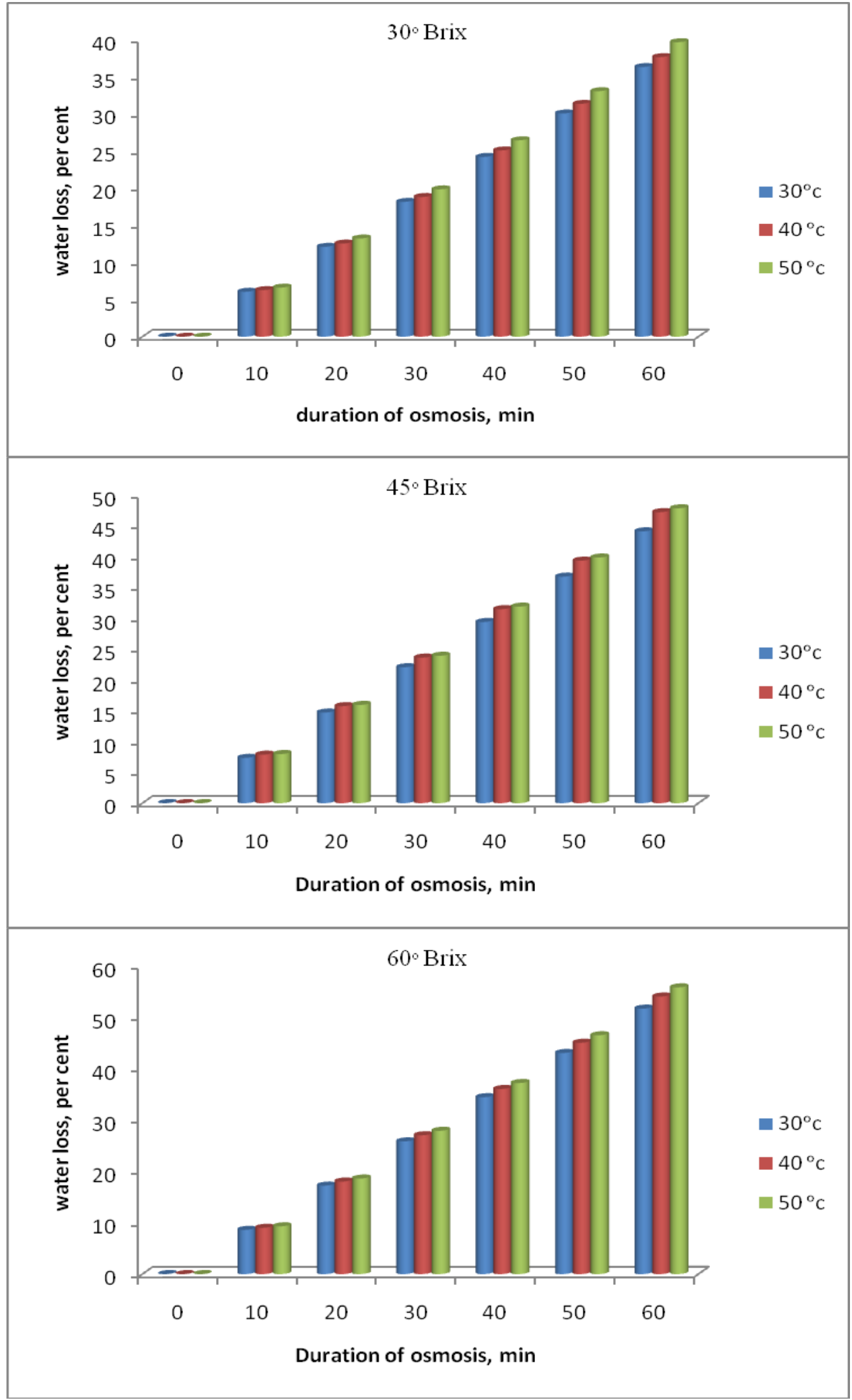


Fig.2 Variation in water loss with temperature at 30,45 and $60^{\circ}$ Brix concentration

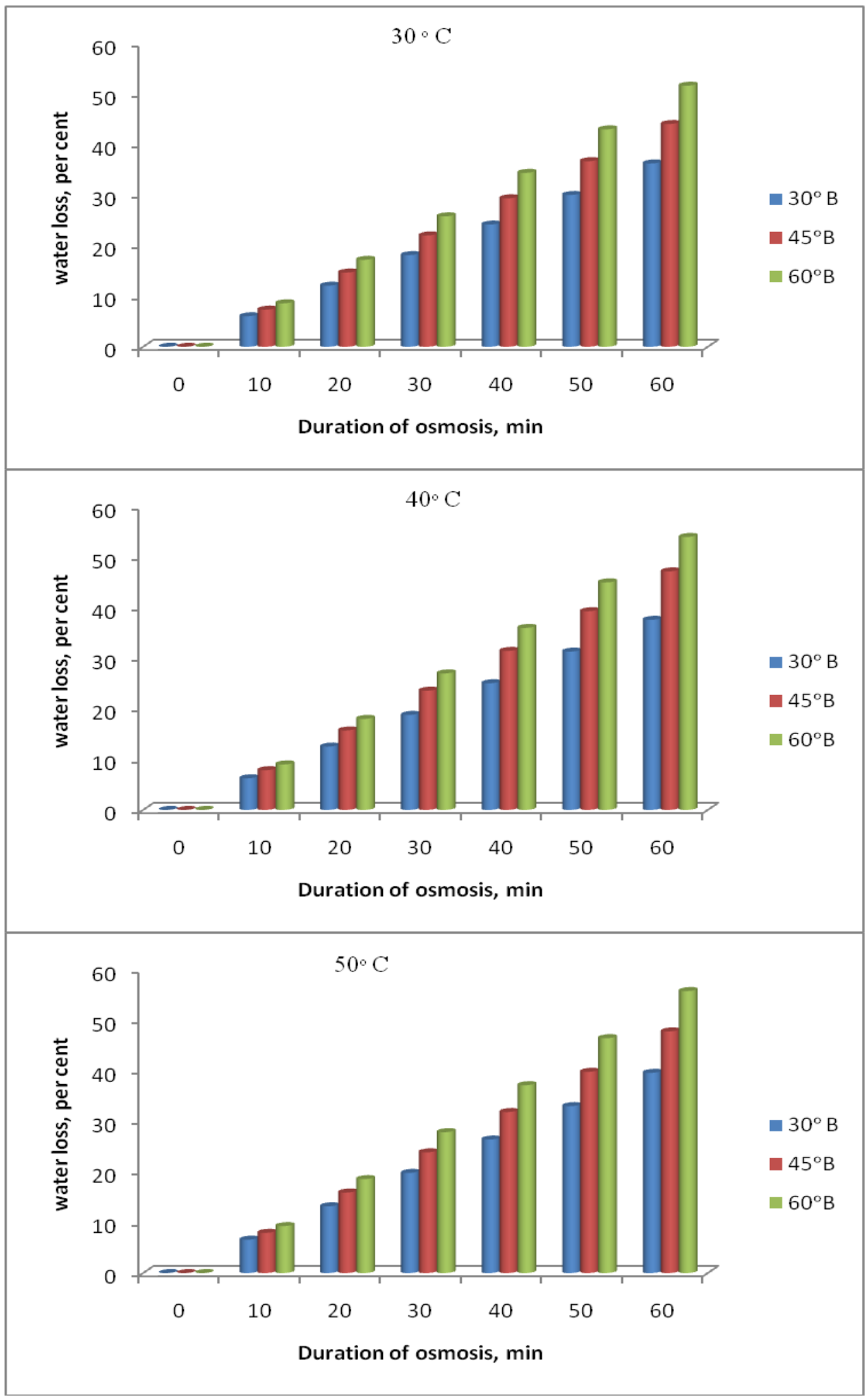


Fig.3 Variation in sugar gain with sugar syrup concentration at 30, 40 and $50{ }^{\circ} \mathrm{C}$ temperature




Fig.4 Variation in sugar gain with temperature at 30,45 and $60{ }^{\circ}$ Brix concentration
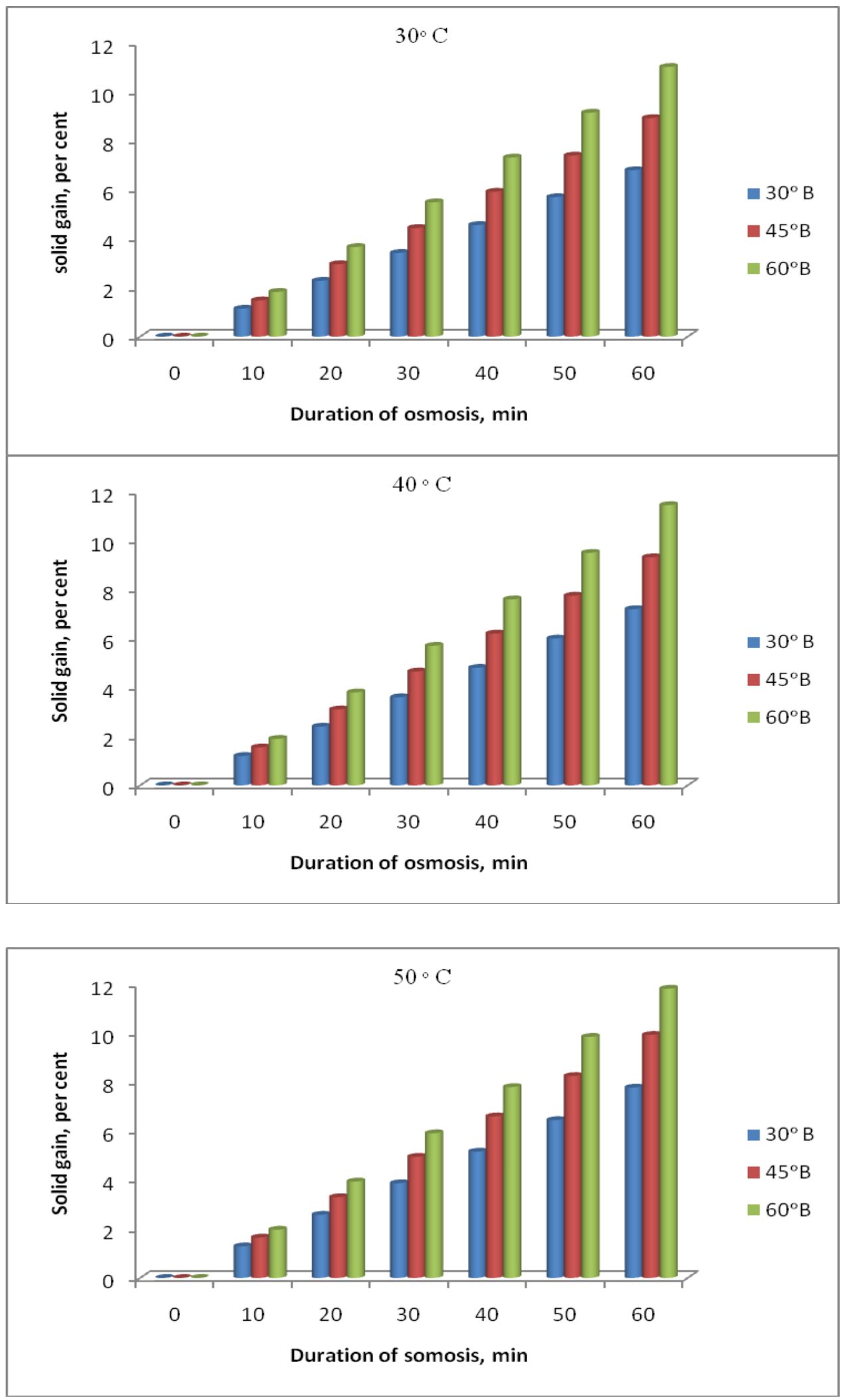
Fig.5 Variation in mass reduction with sugar syrup concentration at 30,40 and $50{ }^{\circ} \mathrm{C}$ temperature




Fig.6 Variation in mass reduction with temperature at 30, 45 and $60^{\circ}$ Brix concentration

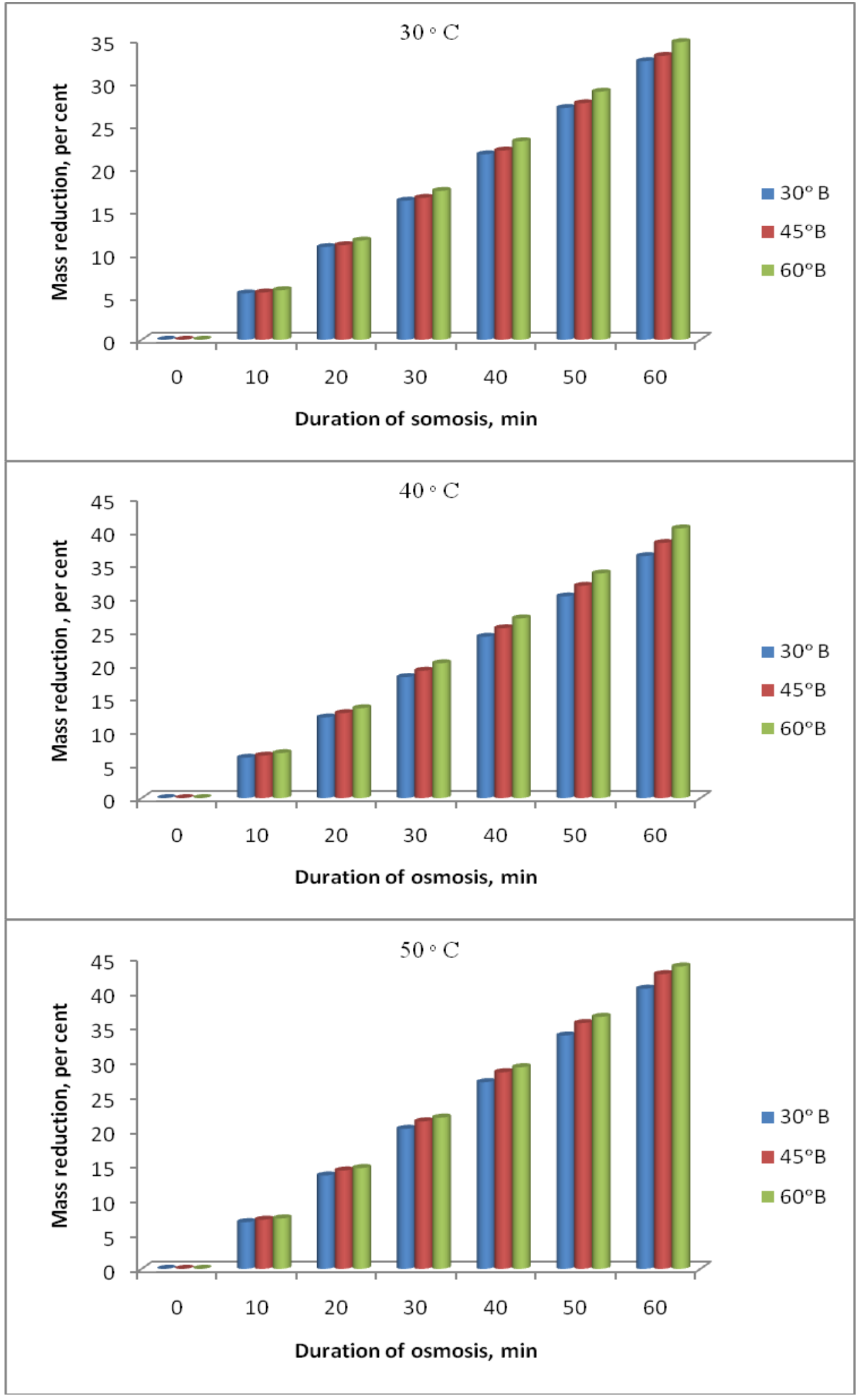


Figure 5 reveals that a low temperature - low concentration condition $\left(30^{\circ} \mathrm{C}-30^{\circ}\right.$ Brix $)$ resulted in a low mass reduction ( 32.50 per cent after $1 \mathrm{~h}$ of osmosis) and a high temp-high concentration condition $\left(50^{\circ} \mathrm{C} \quad-60{ }^{\circ}\right.$ Brix $)$ resulted in a higher mass reduction (43.74 per cent after $1 \mathrm{~h}$ of osmosis). This indicates that mass reduction can be increased by either increasing the syrup temperature or concentration of solution. Similar results have been reported for osmotic dehydration of onions by (Torreggiani and Bertolo, 2001).

Figure 6 shows the variation in mass reduction at 30,45 and $60^{\circ}$ Brix solution concentration at 30,40 and $50^{\circ} \mathrm{C}$ temperatures. The mass reduction at all syrup concentrations was affected by the temperature of the syrup. Mass reduction increased with increase in temperatures.

\section{References}

Biswal, R.N., Bozorgmehr, K. 1991. Equilibrium data for osmotic concentration of potato in $\mathrm{NaCl}$ water solution. J. Food Process. Eng., 14: 237- 245.

Ertekin, F.K., Cakaloz, T.1996. Osmotic dehydration of peas: 2 Influence of osmosis on drying behaviour and product quality. J. Food Process. Preserv., 20: 105 $-119$.

Guroo I, Wani SA, Wani SM, Ahmad M, Mir SA and Masoodi FA.2017. A Review of Production and Processing of Kiwifruit. J Food Process Technol, 8: 699

Gopalan, C., Ramashastri, B.V., Balasubramanyam, S.C.1985. Nutritive value of Indian foods. Ansari nagar, New Delhi, India: Indian Council of Medical Research, Pp. 1- 59.

Jain, R.K., Jain, S.K. 1998. Sensory evaluation of an intermediate moisture product from sapota (Achras sapota L). J. Food Eng., 37: 323- 330.

Jain, S.K., Verma, R.C., Mathur, A.N. 2003. Osmo-convective drying of papaya. Beverage Food World, 30(1): 64- 67.

Karathanos, V.T., Kostaropoulos, A.E., Saravacos, G.D. 1995. Air drying kinetics of osmotically dehydrated fruits. Dry. Technol., 13(5-7): 1503 -1521.

Lazarides, H.N., Katsanidis, E., Nickolaidis, A.1995. Mass transfer kinetics during osmotic preconcentration aiming at minimal solid uptake. J. Food Eng., 25: $151-166$.

Mehta, B.K., Jain, S.K., Mudgal, V.D., Chatterjee, K.2013. Osmotic dehydration characteristics of button mushroom slices (Agaricus bisporus) J. Environ. Ecol., 31(1): 148- 153.

National horticultural board, (2016). Nieuwenhuijzen, N.H., Zareifard, M.R., Ramaswamy, H.S. 2001.Osmotic drying kinetics of cylindrical apple slices of different sizes. Dry. Technol., 19(3\&4): $525-545$.

Nsonzi, F., Ramaswamy, H.S.1998.Osmotic dehydration kinetics of blueberries. Dry.Technol., 16(3-5): 725 -741.

Pisalkar, P.S., Jain, N.K., Jain, S.K. 2011. Osmoair drying of aloe vera gel cubes. J. Food Sci. Technol., 48(2): 183- 189.

Pokharkar, S.M., Prasad, S. A model for osmotic concentration of banana slices. J. Food Sci. Technol., 34(3): 230- 232(1997).

Pokharkar, S.M., Prasad, S. Mass transfer during osmotic dehydration of banana slices. J. Food Sci. Technol., 35(4): 336 338(1998).

Ranganna, S.2000. Handbook of analysis and quality control for fruits and vegetable products. Tata McGraw Hill Publishing Co. Ltd, New Delhi.

\section{How to cite this article:}

Namneet Kaur, Naveet Kaushal, Ajay Singh and Manpreet Kaur. 2018. To Study the Osmotic Dehydration Characteristics of Kiwifruit (Actinidia delicosa) Slices. Int.J.Curr.Microbiol.App.Sci. 7(07): 1931-1941. doi: https://doi.org/10.20546/ijcmas.2018.707.228 